\title{
What Our Students Should Know: Perspectives from Business and Academia
}

\author{
Wayne H. Howard \\ Assistant professor, Department of Agricultural Economics and Business, \\ University of Guelph, Guelph.
}

\section{INTRODUCTION}

Curriculum review is an ongoing part of higher education. New facts, theories and insights are passed along to students as researchers push back the frontiers of knowledge. Problems arise, though, when decisions must be made on what to delete as new information is added to the curriculum. Who makes these curriculum decisions, and to what ends?

One view is that universities, as bastions of elitism and tradition, should decide what collective wisdom and knowledge should be preserved and passed along (Bennett 1984). Moreover, university faculties should be the ones to determine the curriculum and guard against becoming excessively vocational (Study Group on the Conditions of Excellence in American Higher Education 1984). An opposing view is that universities should be responsive to the changing needs of the market and must prepare students to successfully compete in the new age of technology and global competition (Task Force on Education For Economic Growth 1983). The latter view holds that producing an "educated" person is not so much the goal as training the person to become a productive member of society.

The debate has parallels within the agricultural economics profession. Schuh (1986) argues that agricultural economists are too introverted in our discipline and are not contributing to solving society's problems. Beattie and Watts $(1982,102)$ on the other hand, think that learned societies are doing a good job of guiding our discipline to produce " ... timely, high-quality, problem-focused output..." As Beattie and Watts point out, this debate is not new. Wilbur Atwater, the U.S.'s first agricultural experiment station director, in 1887 warned against " ... straining resources in an effort to find a cure for every new problem..." (Kerr 1987, 39).

The question then is: Should curriculum review be guided by the wishes and needs of society, as reflected in the demands by businesses and other organizations for graduates with specific skills, or should the guiding principle be to produce an "educated person" as defined by faculty and their disciplines? The hypothesis of this paper is that, while there will continue to be debate on curriculum content, the curriculum envisioned by academia is not fundamentally different from that envisioned by business. This hypothesis is supported by the results of two inde- 
Table 1. University of Guelph learning objectives.

1 Literacy - the base on which all else is predicated.

2 Numeracy - the ability to use mathematics at a level and in a manner appropriate, which enforces an accuracy and precision of procedure and thought.

3 Sense of historical development - of a discipline and its relationship to broader social conditions.

4 Global understanding - of the political, religious, cultural, geographical, biological, environmental and historical forces shaping the human condition.

5 Moral maturity - a depth and consistency of moral judgment.

6 Aesthetic maturity - a quality of the critical response to some object external to the self, or a process of creation and development of the self.

7 Understanding forms of enquiry - using a methodology based upon systematic study, reflection, intuition and creativity in the search for truth, information, knowledge and understanding.

8 Depth and breadth of understanding -- the ability to draw upon different disciplines in a coherent and productive way.

9 Independence of thought - ranging from a reasoned skepticism at the lowest level to active learning and thinking at a higher level, with a manifestation of love of learning at the highest level.

10 Love of learning - expressed in terms of intellectual curiosity, formulating useful questions, seeing implications and connections, and dissatisfaction with simply accumulating facts.

pendent activities: the defining of university-wide "learning objectives" at the University of Guelph (UG) and the skills required of undergraduate majors in the Department of Agricultural Economics and Business at UG, and a survey of the skills and aptitudes of entry-level managers desired by Canadian agribusiness firms and governmental agencies.

The perspective from academia in the form of the learning objectives at the University of Guelph and the skills required of undergraduate majors in the Department of Agricultural Economics and Business is presented in the next section. The perspective from business follows. A comparison of the two perspectives and the implications of the comparison end the paper.

\section{A PERSPECTIVE FROM ACADEMIA}

The University of Guelph has formally stated the aims and objectives of the university twice since the university was established, once in 1972 and again in 1985. The statement in 1985 led to the UG Board of Undergraduate Studies setting forth learning objectives " ... in terms of the characteristics of educated graduates, and hope thereby to remove the objectives from the plane of abstraction (UG 1986, 1).

The UG learning objectives, with a brief notation on each objective, are reported in Table 1. The objectives are not mutually exclusive; rather they are 
mutually sustaining. Literacy and numeracy are required for further learning; one must understand a form of enquiry and have independent thought to do the research that is a manifestation of the love of learning. Nor can all the objectives be included in every course. It might be difficult ot strengthen a student's numeracy in a literature course, and literacy in a calculus course. But many of the objectives could be addressed in both courses.

The learning objectives are clear on what a university can hope to achieve through education, and on what aptitudes and characteristics it can only judge:

A distinction must be made between those qualities of an educated person for what the University can only screen and act as an authenticating agency, and those which may be generated, or enhanced, by the experiences provided by the University. (p. 1)

A university may accept and graduate only highly motivated persons of high moral character, but education alone cannot instill those desirable characteristics. A university can, however, produce a literate individual trained in the scientific method, whatever that individual's moral character may be.

Faculty have been enjoined to evaluate their programs and courses with the learning objectives in mind, but the objectives "... should not be taken to imply that teaching and programs are currently deficient in respect of attainment of the objectives; indeed many of these are already being met" (p. 1). Where possible, courses should enhance and strengthen the student's knowledge/ability/maturity with respect to the learning objectives. Instructors who keep the overall objectives in mind, rather than a narrow range of disciplinary knowledge, are expected to have a greater impact on the education of a student than instructors who think the objective of a course is transferring facts.

Given the learning objectives, one could say that the preferred graduate is able to obtain information from a string of numbers, communicate that information, and understand the ramifications of that information in an historical and global sense. The information obtained will generate further enquiry bred from a love of learning. Specific disciplinary knowledge assists or is additional to the stated attributes.

\section{Disciplinary Skills in Agricultural Economics}

Partly in response to the university's learning objectives and partly to better define its own mission, the Department of Agricultural Economics and Business (AEB) attempted to identify the unique skills its undergraduate majors should possess upon graduation (Meilke et al 1987). The unique skills are in comparison with other undergraduate majors and are in addition to the " ...other skills/proficiencies and experiences that are necessary for every university graduate. These general competencies and educational attributes..." are the UG learning objectives previously discussed above. 
Table 2. Simple and complex skills required of undergraduate majors in the Department of Agricultural Economics and Business, University of Guelph

Simple skills

1 Ability to locate relevant sources of secondary economic/management data pertaining to agri-food and the economy.

2 Ability to design instruments to obtain primary data.

3 Ability to describe important characteristics of data with summary statistics.

4 Ability to statistically test simple hypotheses.

5 Ability to use commonly available computer software packages for statistical and financial analysis.

6 Ability to construct and interpret the financial statements of a firm and to identify strengths and weaknesses.

Complex skills

7 Ability to work in small groups in addressing economic and management problems.

8 Ability to identify, measure and synthesize the economic/social/political/cultural aspects of situations and be able to conduct benefit/cost analysis.

9 Ability to critically assess the merits of an argument or proposed course of action, using economic and management concepts.

10 Ability to communicate economic and management concepts clearly, both verbally and in writing to:

- an audience of lay persons, and

- a professional audience.

11. The ability to formulate the purpose of an investigation, to identify relevant economic and/or management concepts, to anticipate the form of the solution and to develop a plan of action based on the results of analysis.

The AEB simple and complex skills required for undergraduate majors in agricultural economics, agribusiness and resource economics are reported in Table 2 . The skills are an extension of the UG learning objectives. The first five simple skills all pertain to quantitative research skills: obtaining primary or secondary data, summarizing the data, and using computer software to statistically test simple hypotheses. The sixth simple skill is concerned with the ability to use financial statements. The five complex skills deal with analytical and communication skills. ${ }^{1}$ Competence in the complex skills would mean the ability to work in a small group setting in order to analyze an economic or management problem and then to communicate the findings of the analysis to both professional and lay audiences. As with the UG learning objectives, the AEB faculty were encouraged to examine their courses to see how they might be modified to enhance the teaching of the simple and complex skills outlined above.

\section{A PERSPECTIVE FROM BUSINESS}

The business in this case is agribusiness, including government agricultural services, which employs the majority of the graduates from agricultural colleges. These 
firms and organizations were surveyed using the Agricultural Management Aptitude and Skill Survey (AGRIMASS), following Litzenberg and Scheinder (1987). The survey was designed to elicit the relative importance that agribusiness placed on various aptitudes and skills with respect to the general success of an employee in its firm. Respondents were asked to rank the relative importance of 76 characteristics grouped into six catagories: business and economics; computer, quantitative and management information skills; technical skills; communication skills; personal qualities; and employment, work and general experiences. The relative importance ranged from 1 (of little importance or little proficiency required) to 10 (very important or high proficiency required).

Each firm was sent two surveys: one for a top-level manager (General Manager, CEO, President, etc.) and one for an entry- or middle-level manager. Confidentiality of mailing lists required that some surveys were given to trade associations to address and mail. In all, 287 responses were received from 1134 surveys distributed.

Responses were received from individuals working in a very heterogeneous sample of agribusiness firms in terms of type and size of business, number of employees, and position and length of time with the firm. The type(s) of business(es) surveyed and their characteristics are reported in Table 3 . Several firms listed more than one type of business activity; for example, a grain-marketing firm that also markets seed. About a third of the firms were small, with 35 or fewer employees. However, several firms reported more than 1000 employees. Sales volume also had a broad range, ranging from less than $\$ 10$ million to more than $\$ 1000$ million in sales.

The majority of the respondents were top-level management. About a third were middle-level management, but less than $5 \%$ were entry level. This skewness toward top-level management is thought to be consistent with the objective of the study, as top-level management makes more hiring decisions than do entry-level management. The respondents' length of time with the firm is evenly distributed over fewer than five years to more than 20 years.

\section{Survey Results}

The average rank of a characteristic, ranking of all characteristics, rank of category, and rank within the category are reported in Table 4. Personal qualities were ranked highest overall, with eight of the top ten characteristics within that category, but the average ranking for communication skills was not significantly different. Two of the top ten characteristics were in the communication skills category. Business and economic skills, technical skills, computer, quantitative, and management information skills, and employment, work and general experiences ranked third through sixth, respectively. The average rankings for the second through fifth categories were all significantly different; the difference between computer and quantitative skills and experience was not significanlty different. ${ }^{2}$ 
Table 3. Characteristics of business represented

\begin{tabular}{|c|c|c|}
\hline Summary type(s) business(es) & Number of firms & Percent \\
\hline Food wholesaler/retailer & 19 & $6.6^{\mathrm{a}}$ \\
\hline Food processing/distribution & 52 & 17.0 \\
\hline Dairy processing/distribution & 31 & 10.8 \\
\hline Livestock/meat processing/distribution & 25 & 8.7 \\
\hline Grain processing/distribution & 55 & 19.2 \\
\hline Farm/trade association & 19 & 6.6 \\
\hline Agricultural finance & 18 & 6.3 \\
\hline Agricultural cooperative & 25 & 8.7 \\
\hline Agricultural chemicals, drugs, and fertilizers & 88 & 30.7 \\
\hline Seed production/marketing & 49 & 17.1 \\
\hline Brokerage & 17 & 5.9 \\
\hline Government and other & 62 & 21.6 \\
\hline \multicolumn{3}{|l|}{ Number of employees } \\
\hline 35 or less & 94 & 34.4 \\
\hline 36 to 100 & 49 & 18.0 \\
\hline 101 to 200 & 42 & 15.4 \\
\hline 201 to 500 & 26 & 9.5 \\
\hline 501 to 1000 & 23 & 8.4 \\
\hline more than 1000 & 39 & 14.3 \\
\hline Total & $273^{b}$ & 100.0 \\
\hline \multicolumn{3}{|l|}{ Sales volume $(\$$ million $)$} \\
\hline Less than 10 & 51 & 23.6 \\
\hline 11 to 50 & 77 & 35.7 \\
\hline 51 to 250 & 47 & 21.7 \\
\hline 251 to 500 & 19 & 8.8 \\
\hline 501 to 1000 & 12 & 5.6 \\
\hline Over 1000 & 10 & 4.6 \\
\hline Total & $216^{b}$ & 100.0 \\
\hline \multicolumn{3}{|l|}{ Respondent's position in the firm } \\
\hline Entry level & 12 & 4.2 \\
\hline Middle management & 98 & 34.4 \\
\hline Top management & 175 & 61.4 \\
\hline Total & 285 & 100.0 \\
\hline \multicolumn{3}{|l|}{ Respondent's years with the company } \\
\hline Less than 5 years & 77 & 27.9 \\
\hline 5 to 10 years & 87 & 31.5 \\
\hline 11 to 20 years & 54 & 19.6 \\
\hline More than 20 years & 58 & 21.0 \\
\hline Total & $276^{b}$ & 100.0 \\
\hline
\end{tabular}

${ }^{a}$ sums to more than $100.0 \%$ as some firms have several types of business

${ }^{b}$ not all respondents provided this information 
Table 4. Ratings for all characteristics, average for all firms

\begin{tabular}{|c|c|c|c|c|}
\hline \multicolumn{2}{|r|}{ Description of characteristic } & \multirow{2}{*}{$\begin{array}{c}\begin{array}{c}\text { Average } \\
\text { response }\end{array} \\
5.947\end{array}$} & \multirow{2}{*}{$\begin{array}{c}\begin{array}{c}\text { Overall } \\
\text { rank }\end{array} \\
3\end{array}$} & \multirow[t]{2}{*}{$\begin{array}{c}\text { Rank in } \\
\text { group }\end{array}$} \\
\hline A & Business and economic skills & & & \\
\hline 1 & Read and use financial statement & 6.491 & 33 & 8 \\
\hline 2 & Understand accounting concepts & 6.101 & 35 & 10 \\
\hline 3 & Professional selling skills & 7.157 & 26 & 3 \\
\hline 4 & Marketing administration & 6.961 & 28 & 5 \\
\hline 5 & Corporate finance & 5.656 & 41 & 12 \\
\hline 6 & Human resources planning & 6.403 & 34 & 9 \\
\hline 7 & Micro (firm) economics & 6.927 & 29 & 6 \\
\hline 8 & Macro (Canadian) economics & 5.101 & 52 & 16 \\
\hline 9 & Foreign exchange rates & 4.629 & 62 & 20 \\
\hline 10 & GATT and trade & 4.470 & 63 & 21 \\
\hline 11 & Canadian agricultural policy & 5.305 & 47 & 14 \\
\hline 12 & International trade and export policy & 4.649 & 60 & 19 \\
\hline 13 & $\begin{array}{l}\text { National and international political and } \\
\text { economic forces }\end{array}$ & 4.867 & 59 & 18 \\
\hline 14 & Objectives and goals & 7.547 & 25 & 2 \\
\hline 15 & Business policies and programs & 7.102 & 27 & 4 \\
\hline 16 & Monitor and evaluate performance areas & 7.601 & 24 & 1 \\
\hline 17 & Coordinate human and physical resources & 5.632 & 42 & 13 \\
\hline 18 & Process and product layout and design & 5.747 & 39 & 11 \\
\hline 19 & Inventory management systems & 5.109 & 51 & 15 \\
\hline 20 & Business organizational structure & 6.761 & 30 & 7 \\
\hline 21 & Identify and manage risk and uncertainty & 4.925 & 56 & 17 \\
\hline B & $\begin{array}{l}\text { Computer, quantitative and management } \\
\text { information skills }\end{array}$ & 4.765 & 5 & \\
\hline 1 & General business software & 6.636 & 31 & 1 \\
\hline 2 & Computerized accounting systems & 5.263 & 48 & 4 \\
\hline 3 & Purchase and implement computer systems & 4.272 & 67 & 6 \\
\hline 4 & $\begin{array}{l}\text { Design programs/communicate with } \\
\text { programmers }\end{array}$ & 3.945 & 69 & 8 \\
\hline 5 & Write computer programs & 2.766 & 76 & 10 \\
\hline 6 & $\begin{array}{l}\text { Design and implement management information } \\
\text { systems }\end{array}$ & 4.190 & 68 & 7 \\
\hline 7 & Use computer in management decision making & 6.072 & 36 & 2 \\
\hline 8 & Interpret and use math and statistical methods & 5.714 & 40 & 3 \\
\hline 9 & Use quantitative tech for decision making & 5.144 & 50 & 5 \\
\hline 10 & Understand artifical intelligence & 3.582 & 71 & 9 \\
\hline $\mathrm{C}$ & Technical skills & 5.141 & 4 & \\
\hline 1 & Livestock production systems & 5.444 & 45 & 2 \\
\hline 2 & Crop production systems & 6.516 & 32 & 1 \\
\hline 3 & Specialized crop production systems & 4.873 & 58 & 8 \\
\hline
\end{tabular}


Table 4. Ratings for all characteristics, average for all firms (continued)

\begin{tabular}{|c|c|c|c|c|}
\hline \multicolumn{2}{|r|}{ Description of characteristic } & \multirow{2}{*}{$\begin{array}{c}\begin{array}{c}\text { Average } \\
\text { response }\end{array} \\
4.909\end{array}$} & \multirow{2}{*}{$\begin{array}{c}\begin{array}{c}\text { Overall } \\
\text { rank }\end{array} \\
57\end{array}$} & \multirow{2}{*}{$\begin{array}{c}\begin{array}{c}\text { Rank in } \\
\text { group }\end{array} \\
7\end{array}$} \\
\hline 4 & Soil chemistry and characteristics & & & \\
\hline 5 & Bio-sciences, bio-technology and bio-chemistry & 5.379 & 46 & 3 \\
\hline 6 & Food science and processing technology & 5.000 & 54 & 5 \\
\hline 7 & Food transportation and distribution systems & 5.100 & 54 & 4 \\
\hline 8 & Engineering technology & 4,942 & 53 & 6 \\
\hline 9 & Computer controlled processes & 4.361 & 66 & 9 \\
\hline $\mathrm{D}$ & Communication skills & 8.349 & 2 & \\
\hline 1 & Technical reports & 8.080 & 19 & 7 \\
\hline 2 & Speak clearly and concisely/technical info & 8.384 & 15 & 5 \\
\hline 3 & Give clear and concise instructions & 8.790 & 7 & 2 \\
\hline 4 & Express creative ideas in writing & 8.192 & 17 & 6 \\
\hline 5 & Express creative ideas verbally & 8.493 & 12 & 3 \\
\hline 6 & Read specific technical information & 7.996 & 22 & 8 \\
\hline 7 & Listen to and carry out instructions & 8.857 & 6 & 1 \\
\hline 8 & Listen to and summarize presentations & 7.825 & 23 & 9 \\
\hline 9 & Professional telephone skills & 8.459 & 14 & 4 \\
\hline $\mathrm{E}$ & Personal qualities & 8.354 & 1 & \\
\hline 1 & Provide leadership & 8.613 & 8 & 6 \\
\hline 2 & Delegate responsibility and authority & 8.467 & 13 & 10 \\
\hline 3 & Team player & 8.947 & 4 & 4 \\
\hline 4 & Positive work attitude & 9.249 & 2 & 2 \\
\hline 5 & Self-motivation & 9.263 & 1 & 1 \\
\hline 6 & Self-confidence & 8.607 & 9 & 7 \\
\hline 7 & High moral/ethical standards & 9.056 & 3 & 3 \\
\hline 8 & Work under varied conditions & 8.568 & 11 & 9 \\
\hline 9 & Recognize business opportunity & 8.371 & 16 & 11 \\
\hline 10 & Select and supervise employees & 8.053 & 20 & 13 \\
\hline 11 & Apply technical skills & 8.130 & 18 & 12 \\
\hline 12 & Take and defend position & 8.010 & 21 & 14 \\
\hline 13 & Work without supervision & 8.902 & 5 & 5 \\
\hline 14 & Raise capital for business projects & 4.379 & 65 & 15 \\
\hline 15 & Loyalty to organization & 8.577 & 10 & 8 \\
\hline $\mathbf{F}$ & Employment, work and general experiences & 4.557 & 6 & \\
\hline 1 & Farm/rank work & 5.482 & 44 & 4 \\
\hline 2 & Domestic U.S. agribusiness firm & 5.925 & 38 & 2 \\
\hline 3 & Financial Institution & 3.830 & 70 & 8 \\
\hline 4 & Nonagricultural retail business & 3.369 & 73 & 10 \\
\hline 5 & International agribusiness firm & 4.398 & 64 & 7 \\
\hline 6 & Government/public affairs position & 3.286 & 74 & 11 \\
\hline
\end{tabular}


Table 4. Ratings for all characteristics, average for all firms (concluded)

\begin{tabular}{rlccc}
\hline $\begin{array}{l}\text { Question } \\
\text { number }\end{array}$ Description of characteristic & $\begin{array}{c}\text { Average } \\
\text { response }\end{array}$ & $\begin{array}{c}\text { Overall } \\
\text { rank }\end{array}$ & $\begin{array}{c}\text { Rank in } \\
\text { group }\end{array}$ \\
\hline 7 & Industry internships/co-op work study & 5.173 & 49 & 5 \\
8 & Student teaching assistant/part-time work & 3.480 & 72 & 9 \\
9 & Developing business plan & 5.616 & 43 & 3 \\
10 & Extracurricular activities & 5.950 & 37 & 1 \\
11 & General education - humanities & 4.637 & 61 & 6 \\
12 & Foreign travel/experience & 3.203 & 75 & 12 \\
G & Desired level of education for entry-level management & & \\
1 & Diploma & & & \\
2 & BA & & \\
3 & BASc & & 6 \\
4 & BSc & & \\
5 & BSc(Agr) & & 2 \\
6 & BSc(Eng) & & 1 \\
7 & BComm & & 7 \\
8 & MA & & 3 \\
9 & MAg & & 11 \\
10 & MBA & & 10 \\
11 & MSc & & 5 \\
12 & PhD & & 9 \\
\hline
\end{tabular}

The respondents were asked the preferred degrees for entry level management The BSc (Agr) was the most favored degree. The BSc, BComm., and BASc follow in order of preference. The $\mathrm{PhD}, \mathrm{MA}$, and MAg, not surprisingly, are the least preferred degrees for entry-level positions.

\section{Ranking by Firm Characteristics}

The rankings do not change very much when they are grouped by type of business. Rankings of skills and attribute catagories by firm characteristics are reported in Table 5. Trade associations, firms in finance, chemicals, drugs, and fertilizers, and seed companies ranked communication skills slightly more important than personal qualities. Work experience was ranked higher by trade associations than by other types of firms, and co-ops ranked technical skills higher than computer and quantitative skills, but otherwise the rankings were the same across types of business.

Firms with 200 or fewer employees ranked communication skills higher than personal qualities; the ranking was reversed for firms with more than $200 \mathrm{em}$ ployees. Rankings also changed between computer and quantitative skills and work 
Table 5. Average response by type of industry, number of employees in company, sales volume, respondent's position in company, and respondent's years with the company

\begin{tabular}{|c|c|c|c|c|c|c|c|c|c|c|c|c|}
\hline & \multicolumn{12}{|c|}{ Major Category } \\
\hline & \multicolumn{2}{|c|}{$\begin{array}{c}\text { Business } \\
\text { and } \\
\text { economics }\end{array}$} & \multicolumn{2}{|c|}{$\begin{array}{c}\text { Computer } \\
\text { quantative } \\
\text { management } \\
\text { information }\end{array}$} & \multicolumn{2}{|c|}{$\begin{array}{c}\text { Technical } \\
\text { information }\end{array}$} & \multicolumn{2}{|c|}{$\begin{array}{c}\text { Communication } \\
\text { skills } \\
\end{array}$} & \multicolumn{2}{|c|}{$\begin{array}{c}\text { Interpersonal } \\
\text { skills }\end{array}$} & \multicolumn{2}{|c|}{$\begin{array}{c}\text { Work } \\
\text { experience }\end{array}$} \\
\hline & Average & Rank & Average & Rank & Average & Rank & Average & Rank & Average & Rank & Average & Rank \\
\hline All & 5.937 & 3 & 4.765 & 5 & 5.141 & 4 & 8.349 & 2 & 8.354 & 1 & 4.557 & 6 \\
\hline \multicolumn{13}{|l|}{ Industry } \\
\hline Food wholesaler/retailer & 5.650 & 3 & 4.737 & 5 & 5.375 & 4 & 8.549 & 2 & 8.635 & 1 & 3.871 & 6 \\
\hline Food processing/distribution & 5.980 & 3 & 4.538 & 5 & 5.180 & 4 & 8.440 & 2 & 8.574 & 1 & 3.972 & 6 \\
\hline Dairy processing/distribution & 6.003 & 3 & 4.743 & 5 & 5.202 & 4 & 8.532 & 2 & 8.583 & 1 & 3.363 & 6 \\
\hline Livestock/meat processing/ & & & & & & & & & & & & \\
\hline distribution & 5.960 & 3 & 4.925 & 5 & 5.761 & 4 & 8.093 & 2 & 8.379 & 1 & 4.892 & 6 \\
\hline Grain processing/distribution & 6.188 & 3 & 4.900 & 5 & 5.429 & 4 & 8.094 & 2 & 8.278 & 1 & 4.595 & 6 \\
\hline Farm/trade association & 5.500 & 3 & 4.531 & 6 & 4.753 & 5 & 8.363 & 1 & 8.137 & 2 & 4.760 & 4 \\
\hline Agricultural finance & 6.045 & 3 & 4.427 & 5 & 4.759 & 4 & 8.033 & 1 & 8.025 & 2 & 4.160 & 6 \\
\hline Agricultural co-ops & 6.153 & 3 & 4.655 & 6 & 5.185 & 4 & 8.116 & 2 & 8.461 & 1 & 4.711 & 5 \\
\hline Agricultural chemicals, & & & & & & & & & & & & \\
\hline drugs and fertilizer & 5.737 & 3 & 4.615 & 5 & 5.292 & 4 & 8.423 & 1 & 8.323 & 2 & 4.765 & 6 \\
\hline Seed production/marketing & 5.973 & 3 & 4.748 & 5 & 5.369 & 4 & 8.541 & 1 & 8.425 & 2 & 4.421 & 6 \\
\hline Brokerage & 6.294 & 3 & 3.960 & 5 & 5.281 & 4 & 8.085 & 2 & 8.176 & 1 & 3.838 & 6 \\
\hline Government and other & 6.098 & 3 & 5.116 & 5 & 5.291 & 4 & 8.339 & 2 & 8.450 & 1 & 4.849 & 6 \\
\hline
\end{tabular}




\begin{tabular}{|c|c|c|c|c|c|c|c|c|c|c|c|c|}
\hline \multicolumn{13}{|l|}{ Number of employees } \\
\hline 35 or less & 5.856 & 3 & 4.829 & 5 & 4.915 & 4 & 8.391 & 1 & 8.263 & 2 & 4.388 & 6 \\
\hline 36 to 100 & 6.081 & 3 & 4.820 & 6 & 5.194 & 4 & 8.548 & 1 & 8.505 & 2 & 4.904 & 5 \\
\hline 101 to 200 & 5.831 & 3 & 5.016 & 5 & 5.357 & 4 & 8.325 & 1 & 8.235 & 2 & 4.503 & 6 \\
\hline 201 to 500 & 5.892 & 3 & 4.104 & 6 & 4.947 & 4 & 8.262 & 2 & 8.325 & 1 & 4.250 & 5 \\
\hline 501 to 1000 & 6.339 & 3 & 5.296 & 5 & 6.005 & 4 & 8.314 & 2 & 8.704 & 1 & 4.903 & 6 \\
\hline 1001 or more & 5.995 & 3 & 4.482 & 6 & 5.117 & 4 & 8.094 & 2 & 8.346 & 1 & 4.639 & 5 \\
\hline \multicolumn{13}{|l|}{ Sales volume ( $\$$ million) } \\
\hline 10 or less & 5.922 & 3 & 4.452 & 5 & 4.567 & 4 & 8.253 & 2 & 8.306 & 1 & 4.153 & 6 \\
\hline 11 to 50 & 5.804 & 3 & 4.988 & 5 & 5.133 & 4 & 8.722 & 1 & 8.473 & 2 & 4.608 & 6 \\
\hline 51 to 250 & 6.049 & 3 & 4.572 & 6 & 5.301 & 4 & 8.215 & 2 & 8.446 & 1 & 4.679 & 5 \\
\hline 251 to 500 & 6.110 & 3 & 5.212 & 5 & 4.982 & 6 & 7.971 & 2 & 8.267 & 1 & 5.213 & 4 \\
\hline 500 to 1000 & 5.835 & 3 & 4.954 & 5 & 5.141 & 4 & 8.370 & 2 & 8.440 & 1 & 4.231 & 6 \\
\hline 1001 or more & 5.600 & 4 & 4.089 & 6 & 5.722 & 3 & 8.078 & 2 & 8.607 & 1 & 4.690 & 5 \\
\hline \multicolumn{13}{|l|}{ Position in company } \\
\hline Entry level & 6.686 & 3 & 5.518 & 4 & 4.622 & 5 & 8.648 & 1 & 8.287 & 2 & 4.517 & 6 \\
\hline Middle management & 5.453 & 3 & 4.587 & 5 & 4.937 & 4 & 8.425 & 1 & 8.305 & 2 & 5.375 & 6 \\
\hline Top management & 6.174 & 3 & 4.840 & 5 & 5.264 & 4 & 8.276 & 2 & 8.384 & 1 & 4.666 & 6 \\
\hline \multicolumn{13}{|l|}{ Years with company } \\
\hline Less than 5 years & 5.864 & 3 & 4.635 & 5 & 4.972 & 4 & 8.295 & 2 & 8.301 & 1 & 4.388 & 6 \\
\hline 5 to 10 years & 5.744 & 3 & 4.745 & 5 & 5.024 & 4 & 8.402 & 1 & 8.276 & 2 & 4.597 & 6 \\
\hline 11 to 20 years & 6.132 & 3 & 4.961 & 5 & 5.155 & 4 & 8.312 & 2 & 8.359 & 1 & 4.671 & 6 \\
\hline More than 20 years & 6.117 & 3 & 4.710 & 5 & 5.402 & 4 & 8.292 & 2 & 8.506 & 1 & 4.579 & 6 \\
\hline
\end{tabular}


experience as the number of employees increased, but there was no order to the changes.

Rankings by sales class were relatively stable also. Firms with sales of more than $\$ 1000$ million ranked technical skills higher than did firms with fewer sales. Firms with sales between $\$ 11$ and $\$ 50$ million switched communication skills and personal qualities. Firms with sales of $\$ 251$ to $\$ 500$ million ranked work experience higher than did others, and firms in the $\$ 51$ to $\$ 250$ million class ranked computers and quantitative skills and work experience opposite the other sales classes.

Position in the company seemed to make a difference. Top-level management ranked personal qualities higher than communication skills, the opposite of entryand middle-level management.

Lastly, years with the company had little effect on the rankings. Respondents with five to ten years with the company ranked communication skills and personal qualities opposite of employees who had been with their companies either fewer or more years.

\section{Discussion}

It is not surprising that agribusinesses want self-motivated employees with a positive work attitude and high moral/ethical standards. A preference for good communication skills is also expected. The low rankings of technical skills, computer, quantitative, and management information skills, and experience may be surprising, but they are consistent with similar studies (e.g., Litzenberg and Schneider 1987), and can be explained without resorting to heroic assumptions.

For example, knowledge of exchange rates and GATT and trade ranked 62nd and 63rd, far below 14th-ranked professional telephone skills. Before one bemoans the fate of Canada's international competitive position, note that few entry-level employees will be making decisions affecting a company's international trade. It is far more likely for an entry-level employee to spend considerable time on the telephone, possibly most of it if that employee is in a sales position.

The low ranking of technical skills indicates that the respondents believe that these skills are less important than personal qualities and communication skills. Technical skills may be requisite to gain an applicant an interview, but personal qualities and communication skills will gain the position. It is also possible that business wants employees with certain qualities and abilities, and believe they can teach their entry-level managers the required technical skills. This latter argument can also be applied to the low ranking for computer and quantitative skills. Different companies have different systems, and each industry has its own specialized technology. These results could be an echo of "give me someone who can think, and I'll teach them what to do."

The commonly held belief that experience is important is not supported by these results. However, extracurricular activities, which are usually encouraged 
by most universities, were ranked first within the experience cateogry. In most cases, entry-level employees will not have had many opportunities to gain experience, and so employers look for other attributes. The personal qualities and communication skills employers want may be demonstrated through involvement in extracurricular activities. Again, there is the caveat that experience may be necessary, but not sufficient.

\section{ACADEMIC VERSUS BUSINESS}

Academia and business agreed on the importance of communication skills. Literacy was the first UG learning objective, and all businesses ranked communication skills first or second. Business also valued personal qualities very highly, but the learning objectives were clear that a university can attempt to enhance a student's literary and analytical abilities but only screen for personal attributes. Business clearly wants universities to enhance the communication skills of the students, and would not object to universities screening for desirable (from the perspective of business) personal qualities. ${ }^{3}$

The learning objectives put numeracy second behind literacy, while business ranked computer, quantitative, and management information skills fifth out of six. These rankings are not so divergent if one thinks of the computer and quantitative skills (and fourth-ranked technical skills) as specific disciplinary skills, rather than the broader concept of numeracy as the ability to use mathematics at the "appropriate" level. The hierarchial learning objectives place understanding forms of enquiry and depth and breadth of understanding, which are disciplinary objectives, seventh and eighth, respectively. Business and academia are in more agreement than usually assumed on the relative importance of communication skills and technical skills.

A comparison of the AEB simple and complex skills and the rankings in the survey indicates a degree of consistency between academia and business with respect to disciplinary knowledge. The AEB simple skills were quantitative research and financial analysis skills. Business ranked computer and quantitative skills fifth overall, but within that category the first-, second- and third-ranked skills were an understanding of general business software, use of computers in decision making, and the interpretation and use of mathematics and statistical methods, respectively.

The AEB complex skills emphasized working in small groups, analytical thought and communication skills. Business was clearly in agreement with the importance of communication skills. Being a team player and providing leadership, two attributes necessary for successfully working in a small group, were also highly ranked overall. The importance of analytical thought was not quite as consistent. Business ranked ability to monitor and evaluate performance areas first within the business and economics category, but professional selling skills were ranked higher than an understanding of microeconomics. Those last rankings are 
not surprising when one considers that many entry-level employees will spend more time selling a product or a service than in analyzing the elasticity of demand for that product or service with respect to pricing policy.

\section{SUMMARY}

Perspectives from business and academia on the relative importance of various skills and attributes were compared. The perspective from academia came from the University of Guelph learning objectives and the AEB simple and complex skills required for undergraduate majors. A survey of Canadian agribusiness firms, including governmental agencies, provided the business perspective. Different types and sizes of businesses were consistent in ranking the relative importance of the various skills and attributes. The rankings by business were also consistent with the hierachial learning objectives from the University of Guelph and the disciplinary skills from the AEB. The hypothesis that business and academia are more convergent than divergent as to what our students should know is supported by these results.

Both business and academia rank communication skills highly. Business ranks personal qualities slightly higher than communication skills, but universities recognize that they can only screen for personal qualities, as opposed to the skills that they can enhance through education. Relatively low rankings of technical, computer and quantitative skills and experience should not be interpreted to mean they are unimportant, but rather that they are necessary but not sufficient for entrylevel employees to succeed in agribusiness firms.

\section{NOTES}

${ }^{1}$ There is a twelfth skill: ability to walk on water and part the sea. Since students do not master the first eleven skills, let alone the twelfth, it was suggested that the department chairman enable the committee members to select a few of the most promising undergraduates to spend a week in April on the Florida gulf coast where these and other useful skills can be developed.

${ }^{2}$ The calculated $t$ values for the differences between the average rankings of the categories, in the order they were ranked, were, respectively: $0.0625,22.82,6.163,2.637$ and 1.43 . ${ }^{3} \mathrm{~A}$ reviewer commented that while it may be hard to teach self-motivation, academia can teach such personal characteristics as leadership and ethical business conduct. Recommendations on how to develop agribusiness programs that will impart those important skills are left for another paper.

\section{ACKNOWLEDGMENT}

This study was in part funded by an Agriculture Canada Dean's Grant. The author thanks Mei-Fei Elrich, Larry Martin and Karl Meilke for many helpful comments. The author alone is responsible for remaining errors and oversights. 


\section{REFERENCES}

Beattie, B. R. and M. J. Watts. 1987. The proper preeminent role of parent disciplines and learned societies in setting the agenda at land grant universities. Western Journal of Agricultural Economics 12(December): 95-103.

Bennett, William J. 1984. To reclaim a legacy: A report on the humanities in higher education. National Endowment for the Humanities, Washington, D.C.

Kerr, N. A. 1987. The Legacy: A Centennial History of the State Agricultural Experiment Stations, 1887-1987. Columbia: University of Missouri Agricultural Experiment Station. Litzenberg, K. K. and V. E. Schneider. 1987. Competencies and qualities of agricultural economics graduates sought by agribusiness employers. American Journal of Agricultural Economics 69 (December): 1031-36.

Meilke, K., G. Fox, K. Harling, W. Howard and T. Warley. 1987. Simple and complex skills required of undergraduate majors in the Department of Agricultural Economics and Business. Guelph: University of Guelph, December.

Schuh, G. E. 1986. Revitalizing land grant universities: It's time to regain relevance. Choices 1: 6-10.

Study Group on the Conditions of Excellence in American Higher Education. 1984. Involvement in learning: Realizing the potential of American higher education. Washington, D.C.: U.S. Department of Education, October.

Task Force on Education For Economic Growth/Education Commission of the States. 1983. Action for excellence. Denver, Colo., June.

University of Guelph. 1986. Learning objectives. Guelph, December. 